\title{
SEXUALITY CONSTRUCTION IN CINDERELLA STORY: ASH NOVEL
}

\author{
Nafisa Zafira \\ Universitas Negeri Jakarta, Indonesia \\ zafiranafisa@gmail.com \\ Eva Leiliyanti \\ Universitas Negeri Jakarta, Indonesia \\ eleiliyanti@unj.ac.id
}

Accepted: 2020-04-27 , Approved: 2020-07-06 , Published: 2020-07-20

\begin{abstract}
Recently, there has been a huge increase of sexuality construction studies in literature field including in Young Adult genre. Ash novel is one of young adult genre retelling the classic fairy tale story of Cinderella with the gendering plot twist of the main female character. Instead of construct the main characters to heterosexual, Malinda Lo deconstructs her gender and sexual identity. The aim of this research will focuses on investigating the relationship between the elements of psychosexual development and sexuality construction in the narratives that change the main character's gender and sexual identity. This research are using 5 stages of development theory by Sigmund Freud and performativity theory by Judith Butler. To analyze the narratives, this research is using deconstruction theory by Jaques Derrida as methodology approach. The gendering process and sexuality construction to lesbian appears in several events that bring the main character questioning the masculine role and construct her identity by the dominant stepmother.
\end{abstract}

Keywords: Sexuality Construction; Cinderella; Young - Adult Literature; Lesbian; Psychosexual Development; Performativity, Deconstruction.

\section{INTRODUCTION}

LGBTQ (Lesbian, Gay,

Bisexual Transgender and Queer) is

a community groups that consist of

homosexual that promotes equal

treatment for same sex relationship
(Meyer \& Helis, 2016). According to Meyer and Helis (2016), one of the tool that used to promotes the LGBTQ movements is Media. Khan and Haider (2015) states that media is a communication tool that used to 
convey messages to a larger audiences and it has big impact in society because nowadays people are consuming the media on their daily basis. Here, the community are using the media to promotes their existence and convey the anti-discrimination messages to a larger audiences. There are two types of media that they used, online and offline media. The online media that they are used are facebook, twitter, youtube, instagram, etc., while the offline media are books, news, movies, serials TV and songs. According to Williams and Reter (2003), Henry Gerber was the first icon who break a silence by establishing the first gay rights organization and he get a nomination from the State of Illinois by making the first homosexuality article titled "Friendship and Freedom", in the US. Same as Henry Gerber movements the reclamation can be found mostly in printed media, visual arts and oral narratives, such as; courts and police records, meeting places, organization.

In the printed media, the legalized of LGBTQ bring the young adult writers to make the LGBT novel to educate the young readers to tackle homophobic issue in society. Novel is one of propaganda tool that can influence the readers and make them to accept the new culture, including the acceptance of homosexuality issue (Khan \& Haider, 2015). Young adult is a novel genre that targeted for young readers from 12 to 18 years old (Hay, 2019). It is one of genre that addressed problems, issues, and life circumstances for young readers in order to educate and help them to searching their personal identity (Hay, 2019). Crandall (2016) 
developed that Young Adult literature are not only for the development of young readers' intellectual, but it can solve the 3 differences issues among young readers which are adolescence, female sexuality, and power. It can help adolescents to build their confidence and respect the cultural difference. These tactics are used by LGBTQ young adult writers to persuade the young people to challenge and support the diversity and LGBT rights (Clark \& Blackburn, 2019).

One of the LGBT young adult writer is Malinda Lo. Lo is a lesbian writer that promotes her sexual orientation by writing queer novels. She is a co-founder of "Diversity in YA", a project that celebrates diversity in young adult books. One of her book titled Ash. Ash is retelling classic Cinderella story with a plot twist of main character from straight to lesbian. In the story, Ash is one and only child that must face the died of parents and the cruelty of stepmother and stepsisters. Then she met her godfather Sidhean. In the novel, Sidhean existence is represented as Ash's Father. He likes come and go like her father did to Ash. At the end of the story, Sidhean want Ash to be with him, but she fell in love with a huntress instead. The huntress named Kaisa. Kaisa existence is represented as Ash's mother because she tend to protect Ash and likes to cheer her up. In the end of this story, Ash and Kaisa are ended up to be a lesbian. From the story, Ash is experiencing the gender performativity and sexual desire to woman because the absence of father figure and it guide her to love women figure, which are her mother and her housekeeper. This research is intended to 
investigate the sexuality construction of main female character in young adult novel by Malinda Lo titled Ash. This research are using Performativity Theory by Judith Butler and Five Stages of Psychosexual Development by Sigmund Freud. This research is using the plot analysis in order to analyze the psychosexual development and sexuality construction of the main character.

Performativity theory is the study that argues that gender identity is built by social construction and regulartory practices (Nentwich \& Morison, 2019). Butler's performativity theory has delivering concepts between selves and identities. Butler explains that sex and gender are produced by social norms and regulatory practices which are masculine and feminine. They tend to think that sexuality and gender are interrelated and inseparable. Unlike regulatory practices, she argues that all bodies are part of natural phenomenon, while gender and sex are made by social phenomenon (Morgenroth \& Ryan, 2018). In performativity theory, Butler mainly focused on describing the differences between sexual orientation, sex and how it construct in social norms. Sexual orientation itself explained as the attitudes, feelings, and behaviors of persons that attracted to one or both sexes while sex defined as the genitalia and genetic differences between male and female (Karen, 2018). According to the World Health Organization (n.d), gender defines as:

"Gender refers to the socially constructed characteristics of women and men, such as norms, roles, and 
relationships of and between

groups of women and men. It varies from society to society and can be changed."

American

Psychological

Association (APA) states that there are three kind of sexual orientation, which is heterosexual, homosexual and bisexual (2020). Heterosexual means person who has a sexual desire to the opposite sex, homosexual means person who has a sexual desire to same-sex and bisexual is person who has sexual desire to both sexes. The term of "homosexual" came into use by the second half of the nineteenth century. The term was used as a clinical description of men who displayed sexual desires to other men, but in the modern language the term of homosexuality describes for men and women who likes to same sex (Martos et al, 2017).
Sigmund Freud theory, it holds that a child will experience the five stages of psychosexual development since an infant to puberty. McLeod (2019) states that the the stage of psychosexual development begins from Oral Stage, Anal Stage, Phallic Stage, latency Stage and end up in the Genital Stage. These are called psychosexual stages because each stage represents the fixation of libido or translated as sexual drives or instincts, on a different area of the body. As a person grow up, certain areas of their body become important as sources of sexual pleasure when it is touched (McLeod, 2019).

There are a lot of studies that analyze the identity construction issues as the main focus. Taufiq (2014) displays his interest to analyze the multicultural literature and identity construction in 
Development by Sigmund Freud.

(2011) conduct a research that names as a strategy for identity construction that represented in Nigerian novel. Unlike above studies, this study is focuses on investigate the relationship between the elements of psychosexual development and sexuality construction in the narratives that changes the main character.

\section{METHOD}

To conduct this study, the research design that will be used is Descriptive analytical study. Descriptive analytical study is used to analyze how the writer construct the sexual desire of the main character through several events. In order to find the sexuality construction, this paper are using Gender Performativity theory by Judith Butler and Psychosexual
The data were analyzed by using plot analysis to break down the narratives and classifying the events use Jaques Derida's Deconstruction as method and analyze based on the theories. The data source were taken based on words, sentences and narratives that indicate the sexuality construction of main female character in the remake novel of cinderella's story titled Ash.

\section{FINDINGS AND DISCUSSION}

\section{Origin Story}

'Ash' is taken from the word 'Ashes', it is the other name from Cinderella because in the classic Cinderella story, Cinderella was taken from word 'Cinder'. In the classic Cinderella fairy tales, the story told that Cinderella sleeps among ashes and cinders, and this bring Malinda to take the 'Ash' word because unlike 
the common Cinderella story, Ash were telling the story differently (Malinda Lo, 2009). In the classic Cinderella fairy tales, the story constructs gender stereotypes. In the classic Cinderella, there are a lot of social feminine roles represented in the story. In the story, psychical appearance and social class such as: beauty and luxurious dresses are associates with attracting the royal man (Shaban, 2017). In the story itself, Cinderella is experiencing the discrimination from her steps family and she portraying as obedient, poor and weak, this portrayal classify as gender stereotype.

The other things that make Ash different from Cinderella is the Fairy Godfather and the plot twist to fall for with the huntress instead of the prince. The plot twist are making Ash's sexual orientation changed from heterosexual to homosexual
(Lesbian). The origin fairy on Cinderella story is a women and according to Walt Disney (n.d):

"The Fairy Godmother should have a kindly voice with a certain age in it. I don't see her as being goofy or stupid, but rather as having a wonderful sense of humor".

Walt Disney wants the fairy godmother represents as a mother figure who has a kind, optimist and pure heart, while in the Ash novel, Shidean represents as young fairy godfather who has an exotic body, his cheekbones was sharped as blades, his skin were white as his clothes, his hair were pale as snow. He also has pair of beautiful blue eyes, dark mysterious personalities and silky cold tone. He has strong opinions to several issues and sometimes he does not grant Ash's wishes. 


\section{Exposition}

From Ash novel, there are several events that construct her sexuality to lesbian and it begin from the beginning of the story when her mother died and her father was married to another woman.

In the beginning of the novel, the story told that Ash' father likes to leaving Ash repeatedly. Freud proposed that phallic stage is the key to construct the sexuality of children because in this stage, children are become more aware to the genital differences and erotic attraction between children to their parents, it mainly called as Oedipus complex and Female Oedipus Complex (McLeod, 2019). From the Freud's point of view, the repetition act of leaving Ash will fail Ash to experience female Oedipus complex and it construct her to feel sexual desire for her mother rather to her father (McLeod, 2019). he leave habitual of a father, presents of mother and the failure of Female Oedipus complex process constructs Ash's to experience the same sex relationship (Morgenroth \& Ryan, 2018).

The failure on the phallic stage, fails Ash to experiencing social interaction and communication skill in the latency stage, especially after the death of his mother and the marriage of his father to another widowed in the age of twelve. The range of latency stage itself is from 6 to 12 years old (Fouche \& Holz, 2015). In this stage, the sexual energy has transferred into other function such as personal development, social interaction, communication skill and lead them to be more independent (Fouche \& Holz, 2015). The death of her 
mother and the marriage of his father fail Ash to channel her sexual energy to learn new skill and increase the social interaction between peer group, instead her stepmother and stepsister are not really friendly to her. In the book, it told that she had an argument with one of her stepsister, Ana. It is seen from the narrative,

Ana's eyes narrowed and she stepped out into the corridor, pulling her door shut behind her........ Ash turned her back on there stepsister and began to walk toward the stairs, but stopped when Ana said, "I'll tell. I will wake up your father and tell him your going out."(Lo, 2009, p. 30)

\section{Raising Action}

In the raising action, Ash were experiencing a lot of conflict, including questioning her sexual desire. In this part, it can be seen that Malinda Lo constructs Ash's sexuality to lesbian. The first conflict appears when her father died few months after Marriage and Ash's stepmother began to treat her badly. She ordered Ash to be a helper and assist her stepsisters when study in the age of twelve. Lack of knowledge and minimum of social interaction bring children to experience a lack of self-development and decrease her self-confidence (Fouche \& Holz, 2015). The lack of self-development, bring children to experience homesick, unhappiness, and powerless. To handle above problem, it need a help of parents figure to support and assist their children to face the problem (Fouche \& Holz, 2015). In the novel, instead of support Ash, her 
stepmother order ash to be the helper to pay her father's debt, it can be seen from the what her stepmother told in the narrative,

"If your father had known to manage his finances, you would not be put in the position of paying for his mistakes. As it is, I will expect you to work off his debts without complaint, because you are his daughter and it is your responsibility, Do not shrink your duties."(Lo, 2009, p. 57)

The lack of support, social attraction and self-developments were construct Ash to be a loner and fighter. These factors construct the Ash's gender role has developed into masculine. According to Kachel et al (2016), several research argues that gender is used for measure the masculinity and femininity by looking at how dominant, competitive or affectionate and gentle of one person.

The repetition of gendering process also happened when Ash's stepmother asked her to wearing the livery. Livery is a servant uniform and mainly wear by man. This factor can make Ash experiencing the masculine role rather than femininity role.

\section{The Fairy Godfather}

On Ash thirteen birthday, she met for the first time with her fairy godmother in her mother's grave. In the narrative, Sidhean were helping Ash to go back to her stepmother but Sidhean rarely show himself in front of Ash and he never help Ash to finish her duty as helper. In the beginning of the meeting, Ash showed her interest to Shidean 
because thirteen years old ash is belong to Genital Stage and in this stage, freud discussed that puberty and adolesence is the beginning of sexual desire toward others (Fouche \& Holz, 2015). The failure in genital stage bring many consequences and complex issues to develop children's sexuality and identity, including the unable to have a sexual desire to different sex because of unresolved female Oedipus complex (Fouche \& Holz, 2015). The absence of father figure and Shidean figure repeatedly in Ash daily life, it seen in narrative, "I came to find you", she said, looking up at him. His face was strangely disturbing, his skin like the surface of a pond, but it was also more beautiful than she remember."(Lo, 2009, p. 84)

The absence of Shidhean brings
Ash build a friendship with Kaisa, the King's Huntress of the Royal Hunt. Later, from the narrative, it is told that Sidhean wants to be with Ash by making a deal with her. $\mathrm{He}$ grant Ash's wishes but want Ash to love him in return.

\section{The Huntress}

Ash met Kaisa for the first time in the wood and asked Ask about the buck. Later on, Kaisa help Ash to find a correct path, turns out Ash lie to Kaisa because she know where to go, it can be seen from what Ash said in the narratives,

She felt little guilty because she had to lied to the huntress, and she wondered came to find you", she said, looking up at him. His face was strangely disturbing, his skin like the surface of a pond, but it was also more 
beautiful than she The representation of the prince remember."(Lo, 2009, p. 84) figure in Ash is very minor. For Ash, In the narrative above, Ash shows the prince Aidan was not handsome her interest to Kaisa by lying and accidentally meet Kaisa again in the wood. Kaisa also has an interest to Ash because the next few days, she visit Ash in her place. Then, the next day Kaisa offers Ash to ride a horse and the narratives is closed with the question of Ash to Kaisa of why she here with Kaisa. Later on, Kaisa stated that,

I supposes it seemed as though you were being placed in my path time and time again."... "I wanted to find why."

Ash Asked, do you know the answer?"

Kaisa replied, No, not yet"(Lo, 2009, p. 151)

\section{Climax}

The climax part begin when Kaisa kissed Ash's both cheek several time and Ash kissed her back. It can be seen from this narrative,

\section{The Prince}

Once again she kissed her 
on both cheek but this time Ash kissed her as well, and she wondered when - or if she would see her again.(Lo, 2009, p.220)

In the narratives, it is seen that Ash and Kaisa has sexual desire to one another. Ash's gendering process and psychological development resolved her to be a lesbian. Later, she meet Sidhean and tell that she does not a romantic interest and sexual desire to him.

\section{Resolution}

The resolution is when Ash comes to find Kaisa in the palace. They are telling love to each other. They ended up kissing on each others, it can be seen from the narrative below,

Then they took the last step together, and when she kissed her, her mouth as warm as summer, the taste of her sweet and clear, she knew, at last, that she was home (p. 264).

\section{CONCLUSION}

Ash is one of young adult novel retelling Cinderella story with a plot twist of the main female character. Based on findings and arguments that presented in introduction and discussion, it appears several aspects that construct the gendering process of Ash to be a lesbian, which are; (a) the absence of father figure, (b) the death of mothers, (c) the marriage of father to the evil stepmother, (d) the repetition act of wearing man's apparel, (e) the failure of phallic and latency stage, (f) the loner Ash and the daily present of Kaisa replacing the mother figure for Ash. 


\section{REFERENCES}

American

Psychological

Association. [2020]. Retrieved from

https://dictionary.apa.org/oedip

us-complex

American

Psychological

Association.

[2020].

https://dictionary.apa.org/sexua

I-orientation

Crandal, C. (2016). Reading Power:

Female Sexuality, Bullying,

and Power Relations in Young

Adult Literature. University of

Massachusetts at Amherst

Clark, T., Blackburn, V.(2019)

Reading LGBT-Themed

Literature with Young People:

What's Possible?. Retrieved

from

https://www.researchgate.net/p

ublication/291448707

Fauche, P., Holtz, T. (2015). Roald

Dahl: A psychosexual developmental trajectory study illustrated within

psychobiography. Journal of psychology in Africa.

Hay, M. (2019). Why Do Adults

Read Young Adult Books?

Portland state University. Book

Publishing Final Research

Paper. 35. Retrieved from:

https://pdxscholar.library.pdx.e

du/eng_bookpubpaper/35

Karen, C. (2018). Sex and gender:

What is the difference?

Retrieved from

https://www.medicalnewstoday

. .com/articles/232363\#gender-d ifferences

Katchel, S., Steffens, M. Niedlich, C. (2016)Traditional Masculinity and Femininity: Validation of a New Scale Assessing Gender Roles. Frontiers in Psychology. Khan, A, Haider, K. (2015) Impact of Media Routines on 
Construction of News Stories:

Exploring the Practices of Print

Media Journalists of Multan

Kamran Haider. Pakistan

Journal of Social Sciences

(PJSS) Vol. 35.

Lamidi. T, Aboh, R, (2011. )Naming

as a strategy for identity

construction in selected 21 st

century Nigerian novels. 3L;

Language,Linguistics and

Literature, The Southeast Asian

Journal of English Language

Studies., 17 (2).

LGBT Rights Timeline the Gay Rights Movement is a civil rights. [n.d]. Retrieved from Http://www.breakingprejudice.o rg/

MALINDA LO. [2009]. Retrieved from

http://www.malindalo.com/2009

/09/ash-qa-2-how-did-you-com

e-up-with-the-names/
Map: Same-sex marriage in the United States. [2015, June 26].

CNN U.S. Retrieved from http://edition.cnn.com/interactiv e/us/map-same-sex-marriage/

Martos et al. [2017] Lesbian, gay, bisexual, and transgender (LGBT) health services in the United States: Origins, evolution, and contemporary landscape. Australia: PLOS ONE. Retrieved from https://journals.plos.org/ploson e/article/file?id=10.1371/journal .pone $.0180544 \&$ type $=$ printable McLeod. Saul. (2019).

Psychosexual Stages. Retrieved from Simply Psychology website: //www.simplypsychology.org/ps ychosexual.html Meyer, Heist. (2016). Introduction to Lesbian, Gay, Bisexual, Transgender, and Queer 
(LGBTQ) History in the United

States. Washington, DC:

National Park Foundation.

Retrieved

from

https://www.nps.gov/subjects/lg

btqheritage/upload/lgbtqtheme-

history.pdf

Morgenroth, T., Ryan, M. (2018).

Gender Trouble in Social

Psychology: How Can Butler's

Work Inform Experimental

Social Psychologists'

Conceptualization of Gender?.

Frontiers in Psychology.

Nentwich, J., Morison T. (2017).

Performing the Self:

Performativity and Discursive

Psychology. University of St.

Gallen. Relieved from:

https://www.researchgate.net/p

ublication/321039107

Shaban, E. (2017). Gender
Stereotypes in Fantasy Fairy

Tales: Cinderella. AWEJ for

Translation \& Literary Studies

volume 1 .

Taufiq, A. (2014).

MULTICULTURAL

LITERATURE: THE IDENTITY

CONSTRUCTION IN

INDONESIAN NOVELS.

Retrieved from

https://jurnal.ugm.ac.id/jurnal-h

umaniora/article/view/4659/411

Williams, W. L. \& Retter, Y. [2003].

Gay and lesbian rights in the

United States: A documentary

history. Westport, CT:

Greenwood Press.

Disney Fandom (n.d). Fairy

Godmother Character.

Retrieved from

https://disney.fandom.com/wiki/

Fairy Godmother 